\title{
Professional Self-Concept and Moral Sensitivity in Nursing Students: A Descriptive and Correlational Study
}

\section{Öğrenci Hemşirelerde Profesyonel Benlilk Kavramı ve Ahlalki Duyarlılılk: Tanımlayı̊ı ve İliş̧ki Arayııı Çalışma}

\author{
Mustafa Levent ÖZGÖNÜL ${ }^{a}$, Nurcan KIRCA ${ }^{b}$, Yeliz KARAÇAR ${ }^{c}$, Kerime BADEMLİ ${ }^{d}$
}

\begin{abstract}
This study was conducted to identify the professional self-concept and the related factors among student nurses studying at a nursing faculty and to investigate the relationship between moral sensitivity and the professional self-concept. Method: This was a descriptive and correlational study carried out on 381 nursing students. The Student Information Form, Professional Self-Concept Scale for the Student Nurses, and the Moral Sensitivity Questionnaire were employed as the study tools. Descriptive and inferential statistics were used to analyze the data. Results: A weak and reverse relationship was found between the professional self-concept and moral sensitivity of nursing students. A decrease in moral sensitivity score was correlated with a high professional self-concept. Discussion and Conclusion: There was a correlation between a decrease in moral sensitivity score and a high professional self-concept.
\end{abstract}

Keywords: Moral sensitivity; nursing students; nursing education; professional self-concept $-$

Özet: Bu çalışma, bir hemşirelik fakültesinde öğrenim gören öğrenci hemşirelerde ablaki duyarlılık ile mesleki benli kavramı arasındaki ilişkiyi araştırmak amacıyla yapılmıştır. Yöntem: Bu tanımlayıcı ve ilişki arayıcı çalışma 381 hemşirelik ögrencisi ile yürütülmüstür. Çalışmada veri toplama araçları olarak Öğrenci Bilgi Formu, Öğrenci Hemşireler İ̧̧i Mesleki Benlik Kavramı Ölçeği ve Ablaki Duyarlılık Anketi kullanılmıştır. Verileri analiz etmek için tanımlayıcı ve çıkarımsal istatistikler kullanılmıștır. Bulgular: Hemşirelik ögrencilerinin mesleki benlik kavramı ile ablaki duyarlılıları arasında zayıf ve ters bir ilişki bulundu. Ablaki duyarlılık puanındaki azalma, yüksek mesleki benlik kavramı ile ilişkilendirilmiştir. Tartışma ve Sonuç: Ahlaki duyarlılı puanındaki azalma ile yüksek mesleki benlik kavramı arasında bir korelasyon vardı.

Anahtar Kelimeler: Ablaki duyarlılık; ögrenci hemşireler; hemşirelik eğitimi; profesyonel benlik kavramı

\section{INTRODUCTION}

Ethical reasoning is considered to be important as one of the most significant factor in professionalism. Specialized education, the standard for qualification and high professional ethics are involved in nursing professionalism, thus, the independence of nursing activity is maintained by nursing (1). In general, loyalty to ethics leads to better professional performance and advancement of nurses. It was determined by the authors that there was actually a relationship between the loyalty to professional ethical codes and values and the strength of the nurse professional self-concept (2). Moral sensitivity indicates an ability to be conscious of an ethical conflict, involving both feelings and self-awareness of the person's own responsibilities in ethically

\footnotetext{
${ }^{a}$ Akdeniz Üniversitesi Tıp Fakültesi, Temel Tıp Bilimleri Bölümü, Tıp Tarihi ve Etik Anabilim Dalı, Antalya

bAkdeniz Üniversitesi Hemșirelik Fakültesi Doğum, Kadın Hastalıkları Hemşireliği Anabilim Dalı, Antalya

cAkdeniz Üniversitesi Hemşirelik Fakültesi Psikiyatri Hemşireliği Anabilim Dalı, Antalya

${ }^{\mathrm{d}}$ Akdeniz Üniversitesi Hemşirelik Fakültesi Psikiyatri Hemşireliği Anabilim Dalı, Antalya $₫$ kerimedemirbas@akdeniz.edu.tr

Gönderim Tarihi: 01.01.2021 • Kabul Tarihi: 19.03.2021
} 
sensitive cases (3). The development of necessary skills for ethical decision making, including moral reasoning and moral sensitivity, among students is the crucial objective of ethics education (4). The existing literature indicates that moral reasoning and moral sensitivity have been accepted as the required skills for ethical decision-making by nurse educators $(5,6)$. Nursing education constitutes a chance for internalizing moral sensitivity and improving the professional self-concept. Thus, nurse educators should be conscious of the variables regarding nursing students' moral sensibility and moral sensitivity. Some studies have identified nurses' moral self-concept as being a very important factor influencing moral sensitivity, but there is not enough evidence to support this. In Turkey there is a lack of studies investigating the relationship between professional self-concept and moral sensitivity, and we believe that these factors play an important role in moral decision making in nursing student. Therefore, the present study was conducted to investigate professional self-concept and moral sensitivity in student nurses. The aim of this study was to examine the relationship between moral sensitivity and professional self-concept among nursing students.

\section{METHOD}

\section{Design and sample}

This descriptive and correlational study was conducted on nursing students studying in Akdeniz University Faculty of Nursing from December 2019. This study was conducted to identify the professional self-concept and the relevant factors among student nurses studying at a nursing faculty and to investigate the relationship between moral sensitivity and the professional self-concept. All nursing students in the faculty of nursing constituted the sample of the study. In this regard, 381 students who admitted to take part in the study and filled out the data forms completely were included in the study.

\section{Data collection}

The necessary approvals were received from the Nursing Faculty of Akdeniz University to conduct the study. All nursing students were invited to take part in the study. In this regard, 381 students who admitted to take part in the study and filled out the data forms completely were included in the study.

\section{Measures}

The data of the study were collected through the Student Information Form, Professional Self-Concept Scale for the Student Nurses, and The Moral Sensitivity Questionnaire.

\section{Student Information Form}

Student information form includes questions on the demographic information of the participants, including gender, age, academic year, willingness to prefer nursing as a profession, satisfaction from nursing faculty and course status about ethics.

\section{Professional Self-Concept Scale for the Student Nurses (PSCNSS)}

Sabancıoğulları and Doğan developed and tested this scale for validity and reliability (7). The items are scored on a 4-point Likert scale as follows: 1 (don't agree at all), 2 (disagree), 3 (agree), 4 (completely agree). The scale has 45 items and 3 sub-dimensions, which are "professional satisfaction," "professional competence," and "professional attributes". Occupational satisfaction means nursing students' occupational satisfaction and the individuals' perception of themselves as the members of the profession. Occupational proficiency involves the questions of oneself with regard to occupational qualifications, such as problem solving skills, decision-making, occupational knowledge and skills, and occupational competency required for conducting the nursing student profession. Occupational characteristic involves the questions on the feelings, thoughts 
and beliefs related to the fulfillment and the qualifications of the profession. While 31 items in the scale are scored straight, 14 of them are scored in reverse. The scores obtained from the scale vary between 45 and 180. A high score obtained from the scale indicates that the professional self-concept of the nursing students develops positively. The Cronbach Alpha coefficient of the scale was found to be 0.88 in the original study of the PSCNSS (7). In this study, it was determined that the Cronbach's alpha value of the scale was 0.80 .

\section{The Moral Sensitivity Questionnaire (MSQ)}

Kim Lützén developed the moral sensitivity questionnaire in order to measure the moral sensitivity of nurses working in a psychiatry clinic, and Kim Lutzen's questionnaire was modified by Comrie (2012) in order to measure the moral sensitivity of student nurses (MMSQSN) $(8,9)$. The Turkey version of the Moral Sensitivity Questionnaire (MSQ) was used to measure moral sensitivity (10). The MSQ is a self-administered questionnaire, designed as a seven point Likert scale that consists of 27 assumptions representing six subscales in scoring, the test is divided into six categories: modifying autonomy (professional responsibility), reliance on medical authority (patient-oriented care), moral meaning, expressing benevolence, experiencing conflict, interpersonal orientation (10). An example of such an assumption is that "I believe that good care involves respecting the patient's self-choice." The anchors of each assumption are "I totally disagree" and "I totally agree". For each item, a score of 1-7 indicates the extent of agreement or disagreement with the assumption. Higher scores refer to lower moral sensitivity and vice versa. The Cronbach Alpha coefficient of the scale was determined to be 0.82 in the original study (10). In this study, it was determined that the Cronbach's alpha value of the scale was 0.78 .

\section{Data analysis}

SPSS software version 21.0 package program was used to analyze the data, and descriptive and analytical tests such as one-way ANOVA, Pearson's correlation and t-test were used. Number, percentage, mean, standard deviation, Kruskal Wallis analysis and one-way ANOVA test, Mann-Whitney U test and Independent sample $\mathrm{t}$ test and Spearman correlation analysis were used while evaluating the data. The significance level was accepted as $p$ values less than 0.05 .

\section{Ethical considerations}

Ethics committee approval was received from Akdeniz University Clinical Research Ethics Committee (Date: 11 December 2019, Approval number: 1186). The study was carried out in accordance with the established ethical guidelines of the Declaration of Helsinki. Participation in the study was voluntary. The utilization permit was obtained from the authors of PSCNSS and MSQ. Furthermore, approval to approach nurses was received from the institution where the study was carried out. All participants signed on the consent form prior to data collection and their rights to privacy and confidentiality.

\section{RESULTS}

\section{Demographics}

Nearly $80 \%$ of the students were female. The average age of the participants was $20.23 \pm 1.46$. Almost half of the (55.9\%) participants indicated that they were eager while preferring nursing as profession. Nearly $48.0 \%$ of them were satisfied with the nursing faculty (Table 1). 
Table 1: Demographic characteristics of the student $(\mathrm{N}=381)$.

\begin{tabular}{lll}
\hline Variables & n & $\%$ \\
\hline Gender & & \\
$\quad$ Female & 291 & 76.4 \\
$\quad$ Male & 90 & 23.6 \\
Academic Year & & \\
$\quad$ First & 98 & 25.7 \\
$\quad$ Second & 85 & 22.3 \\
$\quad$ Third & 124 & 32.5 \\
$\quad$ Forth & 74 & 19.4 \\
Willingness to prefer & & \\
nursing as a profession & & \\
$\quad$ Yes & 213 & 55.9 \\
$\quad$ No & 168 & 44.1 \\
Satisfaction from nursing faculty & & \\
$\quad$ Satisfied & 183 & 48.0 \\
$\quad$ Not Satisfied & 47 & 12.3 \\
$\quad$ Unstable & 151 & 39.6 \\
Course Status about Ethics & & \\
$\quad$ Yes & 291 & 76.4 \\
$\quad$ No & 90 & 23.6 \\
Total & 381 & 100.0 \\
\hline
\end{tabular}

Table 2: Distributions of mean scores of students obtained from the scales $(\mathrm{N}=381)$.

\begin{tabular}{ll}
\hline Scale & Mean \pm SD $^{*}$ \\
\hline Professional Self Concept in Nursing Students Scale & \\
Occupational satisfaction & $22.51 \pm 4.03$ \\
Occupational proficiency & $20.09 \pm 3.61$ \\
Occupational characteristics & $92.95 \pm 9.71$ \\
Total & $135.50 \pm 14.64$ \\
Moral Sensitivity Questionaire & \\
Benevolence & $13.20 \pm 4.19$ \\
Conflict & $12.14 \pm 3.07$ \\
Application & $14.30 \pm 3.68$ \\
& $(\mathrm{Min}-\mathrm{Max})$ \\
Holistic Approach & $13(5-33)$ \\
Orientation & $10(4-28)$ \\
Autonomy & $22(7-45)$ \\
Total & $98(30-175)$ \\
\hline
\end{tabular}

*Standart Deviation
Mean (PSCNSS) scores of the student were $22.51 \pm 4.03$ for "occupational satisfaction", $20.09 \pm$ 3.61 for "occupational proficiency" and $92.95 \pm 9.71$ for "occupational characteristics". Mean MSQ scores for "benevolence", "conflict" and "application" were $13.20 \pm 4.19$, $12.14 \pm 3.07$ and $14.30 \pm 3.68$ respectively (Table 2 ).
Mean scores of PSCNSS and MSQ according to socio-demographic factors are presented in Table 3. Occupational characteristics scores of the female students were higher compared to male students $(p=0.001)$. It was found that academic year and the total mean score of the scale were statistically significant $(p=0.041)$. PSCNSS scores of the participants who eagerly preferred the profession and satisfaction with the nursing faculty were higher compared to the participants who initiated their profession unwillingly and were not satisfied with the faculty. When the MSQ scale and socio-

demographic factors of the student participating in the study were compared in terms of the gender $(p=0.026)$ and academic year $(p=0.001)$, it was found that "orientation" score of the scale was statistically significant $(p<0.05)$. It was found that "autonomy" $(p=0.004)$, "benevolence" $(p=0.000)$, "holistic approach " $p$ $=0.000)$, "orientation" $(p=0.000)$ and total mean score $(p=0.000)$ of the student who satisfied with the nursing faculty were statistically significant (Table 3 ). 


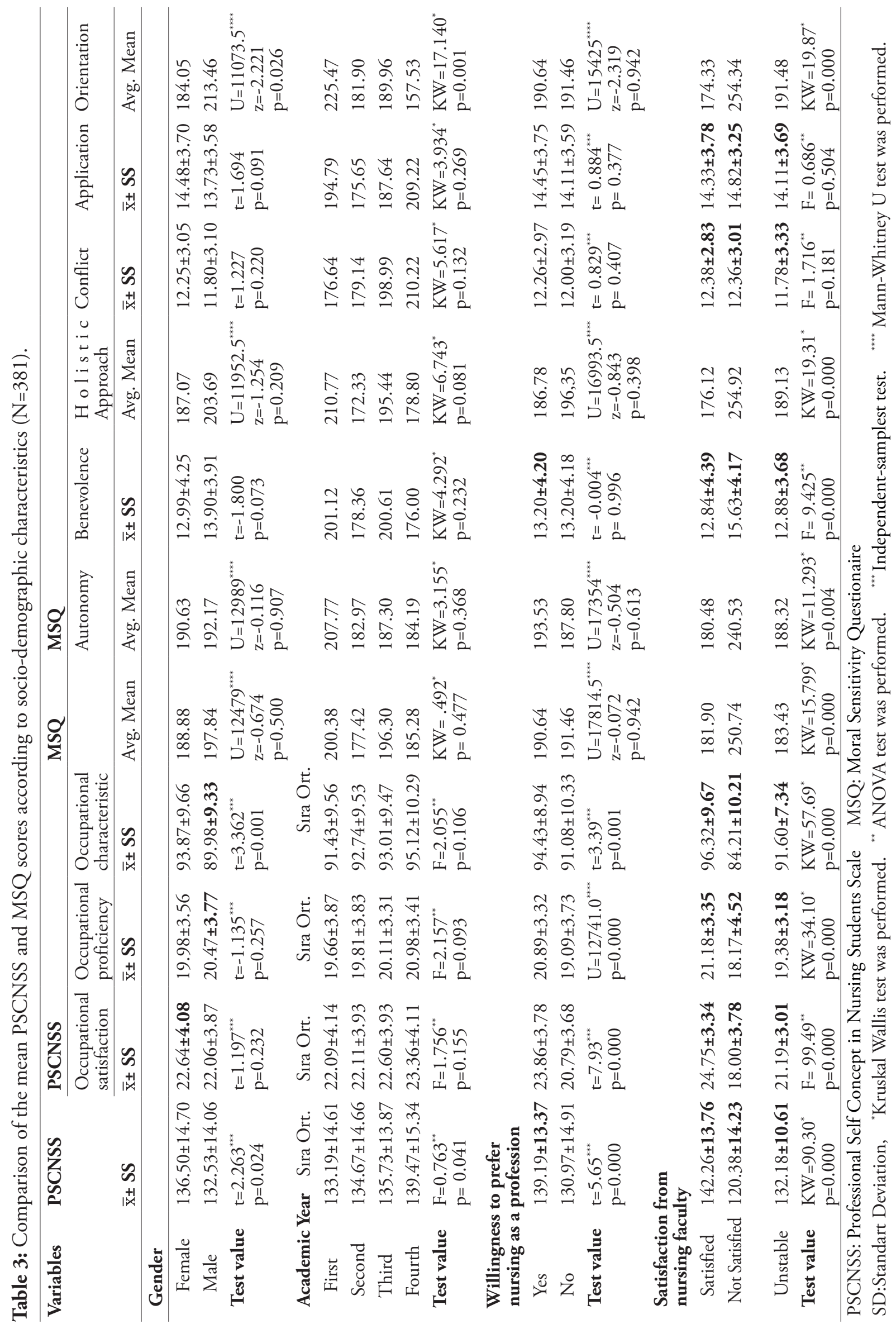


It was determined that there was no statistically significant difference between student nurses taking ethics course and the professional self-concept scale total and sub-dimensions mean scores $(p>0.05)$. It was determined that there was no statistically significant difference between student nurses taking ethics course and the moral sensitivity questionnaire total and sub-dimensions mean scores $(p>0.05)$. Not shown in the table.

Significant, weak negative $(r=-0.207, p=0.000)$ correlations were found between PSCNSS and MSQ (Table 4). Significant negative and weak correlations were found between "autonomy", "benevolence" and PSCNSS. Significant negative and mild correlations were found between PSCNSS and "holistic approach", "orientation". Negative and weak correlations were found between "autonomy", "benevolence", "holistic approach", "orientation" and "occupational satisfaction". It was determined that there were negative and weak correlations between "autonomy", "holistic approach", "orientation" and "occupational proficiency". Negative and weak correlations were found between "autonomy", "benevolence" and "occupational characteristic" (Table 4) (11).

Table 4: Relationship between the PSCNSS and MSQ scores of student nurses (N=381).

\begin{tabular}{|c|c|c|c|c|c|c|c|c|c|c|c|c|c|c|}
\hline \multirow{3}{*}{ Variables } & \multicolumn{14}{|c|}{ MSQ } \\
\hline & \multicolumn{2}{|l|}{ MSQ } & \multicolumn{2}{|c|}{ Autonomy } & \multicolumn{2}{|c|}{ Benevolence } & \multicolumn{2}{|c|}{$\begin{array}{l}\text { Holistic } \\
\text { Approach }\end{array}$} & \multicolumn{2}{|c|}{ Conflict } & \multicolumn{2}{|c|}{ Application } & \multicolumn{2}{|c|}{ Orientation } \\
\hline & $\mathrm{r}$ & $\mathrm{p}$ & r & $\mathrm{p}$ & $\mathrm{r}$ & $\mathrm{p}$ & $\mathrm{r}$ & $\mathrm{p}$ & $\mathrm{r}$ & $\mathrm{p}$ & $\mathrm{r}$ & $\mathrm{p}$ & $\mathrm{r}$ & $\mathrm{p}$ \\
\hline PSCNSS & -0.207 & $0.000^{* *}$ & -0.214 & $0.000^{* *}$ & -0.211 & $0.000^{* *}$ & -0.313 & $0.00^{* *}$ & 0.178 & $0.000^{* *}$ & -0.007 & 0.891 & -0.349 & $0.000^{* *}$ \\
\hline $\begin{array}{l}\text { Occupational } \\
\text { satisfaction }\end{array}$ & -0.084 & 0.100 & -0.101 & $0.049^{*}$ & -0.107 & $0.036^{*}$ & -0.195 & $0.000^{* *}$ & 0.191 & $0.000^{* *}$ & 0.086 & 0.093 & -0.255 & $0.000^{* *}$ \\
\hline $\begin{array}{l}\text { Occupational } \\
\text { proficiency }\end{array}$ & -0.063 & 0.218 & -0.126 & $0.013^{*}$ & -0.062 & 0.224 & -0.122 & $0.017^{*}$ & 0.130 & $0.011^{*}$ & -0.085 & 0.098 & -0.114 & $0.025^{*}$ \\
\hline $\begin{array}{l}\text { Occupational } \\
\text { characteristic }\end{array}$ & -0.241 & $0.000^{* *}$ & -0.214 & $0.000^{* *}$ & -0.250 & $0.000^{* *}$ & -0.344 & $0.000^{* *}$ & 0.140 & $0.006^{* *}$ & -0.015 & 0.774 & -0.378 & $0.000^{* *}$ \\
\hline
\end{tabular}

** Correlation is significant at the 0.01 level (2-tailed). $\quad$ *Correlation is significant at the 0.05 level (2-tailed). PSCNSS: Professional Self Concept in Nursing Students Scale MSQ: Moral Sensitivity Questionaire

\section{DISCUSSION}

This study was conducted to identify the professional self-concept and the relevant factors among student nurses studying at a nursing faculty and to investigate the relationship between moral sensitivity and the professional self-concept. In this study, the mean score of nursing students' professional self-concept was $135.50 \pm 14.64$, which was within the desirable range (45-180). These scores showed that nursing students' professional self-concept developed positively. The same result was also found in another study that was carried out to examine the effect of professional self-concept and professional values of senior students (12). The same result was also found in another study that was carried out among Turkish student nurses (13). Nevertheless, studies indicating moderate-to-low scores from The Professional Self-Concept Scale in nurses are also available $(14,15)$. In the previous studies, it was indicated that higher professional self-concept was associated with the nursing students' professional competence, which is described as an ability to apply knowledge, skills, and attitude to their clinical practice $(16,17)$. The researcher believes that professional self-concept mayaffectthe clinical performance of individuals and end up with greater insight, feelings of responsibility, and professional advancement.

Nowadays, nurses should have information and awareness about professional values as standards to give safe and high-quality ethical care. Moral sensitivity and moral reasoning are the required skills for ethical decision making in nursing practice, and these skills can be taught and learned. Formal education is accepted as an important predictor for moral sensitivity. Ethics is one of the main topics in nursing education. It is 
necessary for student nurses to internalize their professional and ethical roles and to integrate them into their experiences for their education on ethics to efficient (18). Therefore, the determination of the moral sensitivity levels of nursing students is important. In this study, it was determined that moral sensitivity of nursing students was at a moderate level, with an average score of 98 out of 30-210. The same result was also achieved in other studies (19-21). In some of the previous studies, it was determined that the moral sensitivity and orientation scores of nursing students were high $(8,22)$. The different results observed may be due to the lack of a standard in the quality of education in nursing faculties. Nurse instructors are required to continue to improve and incorporate into ethics training strategies that will improve moral sensitivity in nursing curriculum. Thus, a significant improvement can be achieved in terms of the standard of ethics education in nursing education.

The other effective parameter was willingness to prefer nursing faculty, and higher significant professional self-concept scores were found in the participants who preferred the profession with their own will. In other studies, it was indicated that the interest in nursing profession was significantly associated with the professional self-concept and students' decisions to continue in the nursing profession (23). Compared to the students who indicated that they were neutral or not happy with the profession, nursing students who reported that they were happy with the nursing profession were higher (24). It was observed that students' willingness in choosing the profession, love and interest in the profession, and satisfaction with the profession were the factors that contributed to the development of their professional identity (12). The other parameter was satisfaction, and nursing student satisfaction with their faculty found significant and higher moral sensitivity. It needs to be remarked that improvement of professional self-concept and moral sensitivity in all fields may increase nursing students' job satisfaction and feelings of being useful (2).

In the present study, the correlation between professional self-concept and moral sensitivity among nursing students was found to be weak and negative. The study carried out by Paravandar et al. (2015) confirmed this result, in their study, they found significant relationship between nurses' professional self-concept and commitment to professional ethics (2). In this regard, it is important to increase students' education and ethical sensitivity for the positive development of the professional self-concept.

\section{Limitations}

In this study, there were some limitations. Since the context of the study was limited to nursing students in Turkey, the transferability of the results to other student nurses was limited. It is necessary to interpret the results carefully since they may not be generalizable. So, it is recommended to conduct complementary studies with larger samples. Future studies could add some qualitative data to compare contrast and enrich the findings.

\section{CONCLUSION}

Generally, based on the results obtained in this study, a weak and reverse relationship was found between the professional self-concept and moral sensitivity of nursing students. A decrease in moral sensitivity score was correlated with a high professional self-concept. Thus, it is possible to consider reduced professional selfconcept as one of the probable reasons of the reduced moral sensitivity. The results obtained from this research can be useful in solving the reasons related to moral sensitivity among nursing students. Accordingly, nursing educators needs to attempt to provide nursing students with an appropriate level of professional self-concept. Furthermore, interventional studies related to students' self-concept and its effects on their levels of moral sensitivity are subject to further investigation. Thus, it is possible to arrange interventions for encouraging the professional self-concept among nursing students. 


\section{Conflict of interest statement}

None declared.

\section{REFERENCES}

1. Kim KS, Choi JH. The relationship between problem solving ability, professional selfconcept, and critical thinking disposition of nursing students. International Journal of Bio-Science Bio-Technology. 2014;6(5):131-142. https:// doi.org/10.14257/ijbsbt.2014.6.5.13.

2. Parandavar N, Rahmanian A, Jahromi Z. A study of the relationship between nurses' professional self-concept and professional ethics in hospitals affiliated to Jahrom University of Medical Sciences, Iran. Global Journal of Health Science. 2016;8(4):82-88. https://doi.org/10.5539/gjhs.v8n4p82.

3. Yeom HA, Ahn SH, Kim SJ. Effects of ethics education on moral sensitivity of nursing students. Nursing Ethics. 2017;24(6):644-652. https://doi.org/10.1177/0969733015622060.

4. Park M, KjervikD, Crandell J, Oermann. The relationship of ethics education to moral sensitivity and moral reasoning skills of nursing students. Nursing Ethics. 2012;19(4):568-580. https://doi.org/10.1177/0969733011433922.

5. Kim WJ, Park JH. The effects of debate-based ethics education on the moral sensitivity and judgment of nursing students: A quasi-experimental study. NurseEducation Today. 2019;83:104200.https://doi.org/10.1016/j. nedt.2019.08.018.

6. Tuvesson H, Lützén K. Demographic factors associated with moral sensitivity among nursing students. Nursing Ethics. 2017;24(7):847-855. https://doi.org/10.1177/0969733015626602.

7. Sabancıoğulları S, Doğan S. Professional self-concept scale in student nurses; development, reliability, validity. Ege Üniversitesi Hemşirelik Fakültesi Dergisi. 2011;27(2):35-45. (in Turkish)

8. Comrie RW. An analysis of undergraduate and graduate student nurses' moral sensitivity. Nursing Ethics. 2012;19(1):116-127. https://doi.org/10.1177/0969733011411399.

9. Lützén K, Evertzon M, Nordin C. Moral sensitivity in psychiatric practice. Nursing Ethics. 1997;4(6):472-482. https://doi.org/10.1177/096973309700400604.

10. Tosun H. Moral sensitivity questionnaire (MSQ): Turkish adaptation of the validity and reliability. Journal of Contemporary Medicine. 2018;8(4):316-321. https://doi.org/10.16899/gopctd.467052. (in Turkish)

11. Cohen J. Statistical Power Analysis for the Behavioral Sciences. Second Edition. New York: L. Erlbaum, 1998;p.109-139.

12. Coplu M, Tekinsoy Kartin P. Professional self-concept and professional values of senior students of the nursing department. Nursing Ethics. 2019;26(5):1387-1397. https://doi.org/10.1177/0969733018761171.

13. Yilmaz F, Sabancıoğulları S, Kumsar AK. Motivation in the first year of nursing education: it's relationship with professional self-concept, self-esteem archives of nursing practice and care. Archives of Nursing Practice and Care. 2016;2(1):50-56. https://doi.org/10.17352/2581-4265.000014.

14. Barry A, Parvan K, JabbarzadehTabrizi F, Sarbakhsh P, Safa B. Is professional selfconcept associated with stress among nursing students in clinical setting: A descriptive correlational research. Crescent Journal of Medical Biological Sciences. 2019;6(2):191-195.

15. Kelly S, Courts N. The professional self-concept of new graduate nurses. Nurse EducPract. 2007;7(5):332-337. https://doi.org/10.1016/j.nepr.2006.10.004.

16. Gardulf A, Florin J, Carlsson M, Leksell J, Lepp M, Lindholm C, et al. The Nurse Professional Competence (NPC) scale: A tool that can be used in national and international assessments of nursing education programmes. Nordic Journal of Nursing Research. 2019;39(3):137-142. https://doi.org/10.1177/2057158518824530.

17. Kim JS. Relationships between reality shock, professional self-concept, and nursing students' perceived trust from nursing educators: a cross-sectional study. NurseEducation Today. 2020;88:104369. https://doi.org/10.1016/j. nedt.2020.104369.

18. Sahin SY, Iyigun E, Acikel C. Validity and reliability of a Turkish version of the modified moral sensitivity questionnaire for student nurses. Ethics\& Behavior. 2015;25(4):351-359. https://doi.org/10.1080/10508422.2 014.948955 . 
19. Akça N, Şimşek D, Arslan N, Şentürk D, Akça S. Moral sensitivity among senior nursing students in Turkey. International Journal of Caring Sciences. 2017;10(2):1031-1039.

20. Borhani F, Abbaszadeh A, Hoseinabadi-Farahani MJ. Moral sensitivity and its dimensions in Iranian nursing students. Journal ofMedical Ethics and History of Medicine. 2016;9:1-7.

21. Rahnama F, Mardani-Hamooleh M, Kouhnavard M. Correlation between moral sensitivity and self-esteem in nursing personnel. Journal ofMedical Ethics andHistory of Medicine. 2017;10:16.

22. Ahn SH, Yeom HA, 2014. Moral sensitivity and critical thinking disposition of nursing students in Korea. International Journal of Nursing Practice. 2014;20(5):482-489.https://doi.org/10.1111/ijn.12185.

23. Badiyepeyma Z, Hojjat M. The relationship between professional self-concept and nursing students' decision for job retention. Journal of Pharmaceutical and Biomedical Sciences. 2014;4(2):156-161.

24. Kim DH, Moon S, Kim EJ, Kim YJ, Lee S. Nursing students' critical thinking disposition according to academic level and satisfaction with nursing. Nurse Education Today. 2014;34(1):78-82. https://doi.org/10.1016/j. nedt.2013.03.012. 